\title{
MOVE FOR MOVEMBER: REFLECTIONS ON EXPERIENTIAL LEARNING ACTIVITY FOR COLLABORATIVE LEARNING AND PEER LEARNING
}

\author{
Rajeev Chawla and Marianne Cherrington
}

\section{INTRODUCTION}

Experiential learning is integral to the teaching philosophy at Otago Polytechnic Auckland International Campus (OPAIC), especially in the Postgraduate Diploma in Applied Management. Experiential Learning Theory (ELT) provides a holistic model of the learning process and a multilinear model of adult learning and development, both of which are consistent with how the individuals learn, grow and develop. Another reason the theory is called "experiential" is its intellectual origins in the experiential works of Dewey, Lewin, and Piaget. Taken together, Dewey's philosophical pragmatism, Lewin's social psychology, and Piaget's cognitive-developmental genetic epistemology form a unique perspective on learning and development (Kolb, 1984). With a focus on industry-relevant teaching, students deepen their knowledge and understanding of current management capabilities and issues in a range of applied settings using pragmatic strategies and reflective practice. To ensure the 'Leadership in Action' paper had real-life challenges in leadership capability, students experimented with strategies to carry out 'Movember' on campus in Term Five, 2019. This article outlines the teaching strategy and management theories that formed the basis for 'Leadership in Action.' By following the progress of students using feedback and reflection, ideas for practical classroom experiences are highlighted. A surprising collaboration took place for more profitable results and deep learning; it ensured the Movember experience was impactful for all participants, enlivening campus culture with a collegial spirit.

Movember is the "leading charity changing the face of men's health... and suicide prevention, transforming the way health services reach and support men" (Movember, 2020). Finding a charity event for students to get behind is not difficult; New Zealand has many causes with which students connect. Movember in the month of November, which nestled conveniently between Weeks 3 and 6 of an eight-week, final term at OPAIC, 2019. Was 'men's health' relevant to a group of young international students? Of course. We care for humanity, and victims of depression or suicide need awhi (embrace and support). With approval for the event, we began. We explored leadership in action.

\section{LEADERSHIP AND FOLLOWERSHIP}

Why should we study leadership? Admittedly, we can not all be leaders. Consider how some famous leaders think. How many of those leaders are deceased? How many have questionable ethics? How many are inspirational? We need more leaders and leadership; like playing the violin, it is a skill that can be learned and honed.

It began on a Monday morning on campus with 23 postgraduate Applied Management students. Recognising several senior students, it was reassuring to know that the OPAIC teaching approach would be familiar; selfdirected learning would be required for a campus Movember event. We used icebreakers with a 'lead and follow' nuance, then we discussed leadership, followership and 'how to create a movement' (Sivers, 20 I0). 
The first assessment was a report on leadership style in specific situations and cultural contexts. We began with leadership theories (trait, behaviour, contingency and transformation) which led to a discussion on leadership styles (Manning \& Curtis, 2014). Exercises helped visualise leadership style using radar charts. We looked at Change Theory in particular and shared stories about choosing to take the lead or deciding to be a follower and the situations and contexts that framed those decisions. We named famous leaders, and in a class of international students, some surprising examples were shared and various perspectives explored. Inevitably, ethics and motives are integral to these conversations, and inspiring personal stories were revealed.

The next class began with Greta Thunberg's Ted Talk (Thunberg, 2018) and we discussed issues for 2020. We looked back and reflected on Whina Cooper and her moko on hikoi to Wellington (Keane, 2017). We looked at the leadership equation, 'matching the qualities of leaders, characteristics of followers and the nature of the situation,' and we began to consider how to strengthen that three-legged stool in the context of Movember.

The students then decided which of four teams they would like to be part of based on their abilities and inclination. There was a Project Management Team, a Communications Team, an Operations Team and a Finance Team. Only three students chose finance, but that small solid group was confident and all teams were excited to begin. We began brainstorming. A student took notes on the whiteboard as ideas arose. With the Movember website on a screen, we searched for information as required and began to come up with a ranked list of possible ideas and fundraisers. We developed a calendar and a template for meetings; deadlines loomed! With just one week to go, students designed a poster to create some interest; we would launch the first Movember event with photos and fake moustaches. See Figure I.

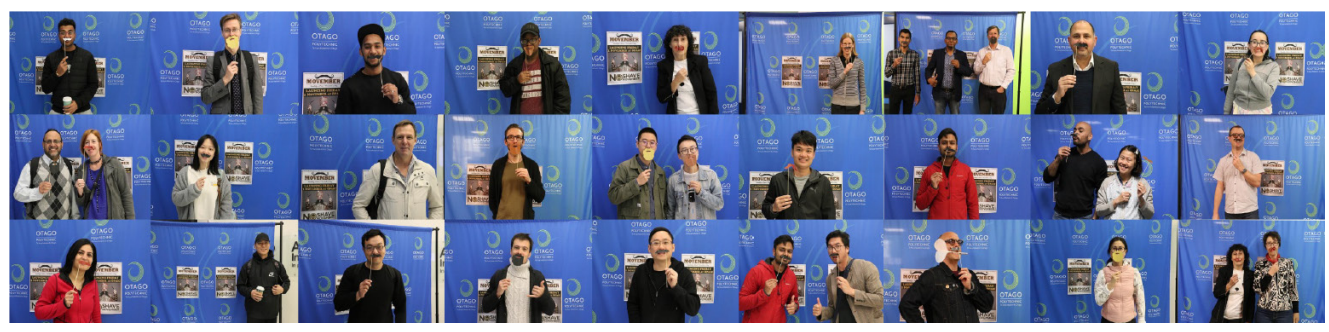

Figure I: Movember Launch 2019, at Otago Polytechnic Auckland International Campus, with posters and fake moustaches.

\section{ACTION PLANS AND AGILITY}

It was a struggle keeping the theory on track; everyone wanted to make a poster. We used the "law of forced efficiency' with a deadline to refocus (Tracy, 2017). Students drafted more of their assessment before they could have a break. We returned and re-ranked our ideas from a financial perspective. We needed seed money. In the spirit of fundraising and communicating awareness, we decided to launch a '30-day, $\$ 30$ Challenge': sponsors would get a Movember Calendar in exchange for pledging one dollar 'saved' each day. Leadership students 'buddied up' and spread the word around campus; we had over 30 pledges by the end of the class. As the initiaves progressed, even the shy students participated with high energy and enthusiasm. The initiative was not quite 'money in the bank', but we did get two 'paid in advance' to kick-start our venture. At the next class, students had their assessments well underway. Key leadership concepts had been introduced, and students were planning a 'Chai Chat' - $\$ 5$ deals at break time and lunch so students could talk about Movember, or anything else. More posters were made; I enlisted our Content and Communications Specialist to take photos of our fake moustache launch at the start of November as students and staff arrived on campus (Otago Polytechnic Auckland International Campus, 2019). We had public relations for our website! 
We learned and used 'Agile' methodologies. In Agile firms, small, diverse teams (with a 'scrum master' and 'product owner'), visualise tasks in columns of 'to-do', 'in progress' and 'done.' Typically, there is a 'daily stand-up' (to get on track), 'sprints' (where products are planned, developed and actioned) with 'reviews and retrospectives' (reviews and debriefs for consistency and quality) as in figure 2. An Agile Scrum Framework was a secure means of getting our four teams' initiatives and ideations communicated within each group. Working across teams helped mitigate the potential for silos (Kropp, Meier, \& Biddle, 20I6). We also used a buddy system to communicate these fast-evolving initiatives throughout the campus. In this way, perceived language issues were assuaged, and more confident students could model constructive approaches (Seki, 2016).

\section{The Agile - Scrum Framework}

\section{Inputs from Executives, \\ Team, Stakeholders, \\ Customers, Users}

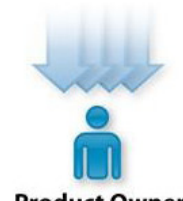

Product Owner

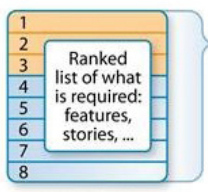

Product

Backlog
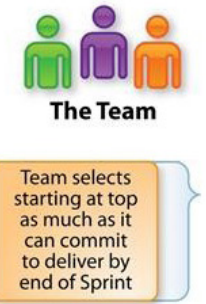

Sprint

Planning

Meeting

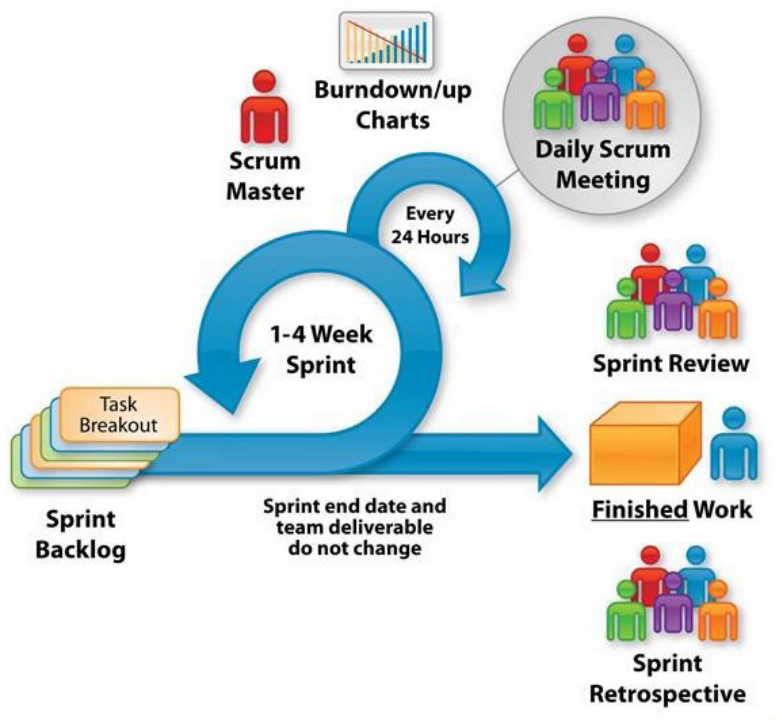

Figure 2. Agile Framework for iterative product and process improvement (Yelkar, 2017).

Traditional leadership does not lend itself to Agile organisations; however, self-organising, diverse teams do require leadership skills especially in the context of situationally dependent leadership and followership roles. In terms of contemporary industry capability demands, there is an overwhelming need for graduates to have wide-ranging problem-solving and decision-making competencies to surmount operational rigidity or dynamic contexts. By exploiting autonomous specialisations with team synergies, Agile frameworks overlay order, organisation and collective intelligence that can generate competitive advantage (Parker, Holesgrove, \& Pathak, 20I5).

Spark had 'gone Agile' in 2018 (Dann, 2018) and many employees who did not want to get agile left the organisation. Industry feedback via our Permanent External Advisory Committee (PEAC) required students to be work-ready so experiencing Agile methodologies became a key focus. As a means of project managing to meet deadlines with diverse groups, Agile made sense. It is visual, tactile, and aural; it pivots when things go awry. Everyone had a meaningful say in the process. We integrated some of these Agile principles by writing on whiteboards and using them on team meeting templates. We continually checked in to keep the students on track of their goals and objectives. 
We finished the week with a plan that would be actioned on the following Monday morning. We would have 'Chai Chats' at morning break and lunchtime, with a slice of pizza and a beverage for $\$ 5$. We finished the week with a visit from the Strategic Management class who added their viewpoints, comments and advice. The students' peers in the Strategic Management class were already spotting issues that we were too busy to notice.

As part of the initiative to entice peers and other stakeholders, the student teams organising Movember had been visiting all the classes on campus. They had been delivering a pitch for the event and seeking confirmation and commitment from fellow students. One of the classes they visited was Strategic Management. These students were exploring and analysing the concepts of 'Vision', 'Mission' and 'Internal Analysis' using the case study from Harvard Business School on Apple Inc. They were brainstorming, and the activity was an opportunity for them to apply the strategic management concepts in real-time for this event. One of the first things they noticed was a difference in understanding of the event among team members.

Additionally, the pitch was not inspiring and lacked a vision. After seeking permission from the lecturer of Leadership in Action, students from the Strategic Management class decided to share the concepts of Vision and Mission with the students of Leadership while connecting these to the characteristics of a leader. It was suggested to change the event sales pitch by changing the promotion of the event from 'what' the event is all about to 'why' the event is being organised for the charity. It was heartening to see the Strategic Management students embrace the event as their own and take responsibility for success by applying the principles of strategic management. As part of goal-setting, each of the four teams from the Leadership in Action class took on selling raffle tickets and mapped each team's success to an overall goal.

\section{JUST-IN-TIME LEARNING AND TEACHING}

We should have been ready with Chai Chat for Monday but we had not all understood the idea that commitments must be followed through. We had a debrief and avoided accusations, but the truth was that the Chai Chat for morning break was not ready. Movember was here; we were to lead and take action. We used the Agile methodologies to regroup and re-energise. Repeating a fundraiser twice a day, every day of the week was exhausting, but we needed to focus any frustrations on the process of improvement using Agile methodologies.

We reaffirmed our commitments and were ready for Chai Chat at lunchtime. Enthusiasm and pizza won the day, and the day after, and the day after that. It turned out to be a lot of effort for small reward. There was a minor insurgence. It was a lesson in small business, nonetheless. The finance team counted the coins earned and tallied up that we had spent more than we had collected. We reflected, soul searched and learned lessons. We had lots of beverages for the next week; the Communications Team decided Chinese dumplings were required for the next week and they would make them! A new product iteration was to be trialled in week two, and product ownership moved from the operations team to the communications team.

On Monday, 'buddies' delivered Chai Chat invitations room by room, and the new menu was well received. The dumplings were delicious, but we ran out of stock. In our debrief, we felt triumphant, but a new kind of weariness had crept in; it was easier to bring pizza in than to make dumplings every day. It was decided that Chai Chat would only occur twice a week, on 'in class' days and that dumplings could be purchased and served with miso soup. We began to make a profit, mainly because beverages were already in stock, and valuable lessons were learned. The Strategic Management class asked if they could join the leadership class after the break to give us feedback from a customer and student perspective.

The Strategic Management students agreed that the new plan was working, but the issue of resource management had been a challenge for broader success. We all were running short of ideas. The Strategic Management team suggested evaluating whether the concept of value proposition could be applied here. At this stage, the internal environment for efficiency was working but not productive. It came down to the lack of resource of available 
money to spend to bring in stock. Two main points came out of the brainstorming sessions: (I) look at the external environment principles and see what else can be done; and (2) consider how to sell more raffle tickets to collect more money, and hence resources, to use in the activity for a profitable outcome. For the external environment, it was agreed that we could reach out to our corporate partners for sponsorship. This ensured partners had visibility of their products and services during the event and also had the opportunity to participate in the Movember charity event as part of their social responsibility commitments. The sales pitch also changed at this stage to make prospect participants see the value proposition by entering their tickets into a raffle where they could win products valued at more than the ticket. The marketing department committed to providing bottles of wine as their contribution to prizes for the raffle.

The feedback and brainstorming that resulted were exactly what was needed: open communication is what good leaders nurture and great businesses use to improve offerings. We rechecked our ranked list of ideas and decided it was an excellent time to reconnect with our challenge sponsors. We realised that raising funds was not our only goal. Awareness was vital, and we decided to connect and partner with the OPAIC mental health initiative. We joined their lunchtime sessions supplying biscuits and coffee at no charge. We decided that a more controlled Chai Chat twice a week would generate better support and that getting feedback and advice from the Strategic Management class was an excellent idea. We ruled out several other strategies but began to think about a sponsored auction in the final week as a low-cost, high revenue and fun campus event. For weekend homework, students would canvas businesses that they had associations with for items to auction.

\section{VISIONARY LEADERSHIP AND SERVANT LEADERSHIP}

With two weeks left for the final event for Movember, we were still trying to agree on a financial target for our Movember project. Only three students had attempted to find auction sponsors so any meaningful financial goal seemed tenuous. It was all part of Leadership in Action experiential learning; we went back to our brainstorming list of ideas, and students began to put the fun back into Movember. With one big 'send-off' event, they could lift spirits by using fun and games to conclude Movember before term-end. Without spending money, competition and auction tickets could bring in funds, such as a school gala day. It would be 'pure profit.' We called this 'Move for Movember.' Finally, a financial goal of $\$ 2000$ was set as the '30-day, $\$ 30$ Challenge' pledges were yet to come.

Students were reinvigorated with their visionary goal and by the idea of achieving outcomes in a fun and beneficial way. Assessment Two required students to write a reflective essay, with a one-page team plan and a portfolio of evidence of their leadership actions as tasks, responsibilities and achievements. Their Agile teamwork was creating a record; personal leadership growth could be shown via a self-assessment matrix including:

- $\quad$ ethical participation in various team roles to inspire others and self to achieve desired outcomes

- evaluation of self-leadership action using reflective practices and feedback for leadership development.

'Chai Chat' was now part of our Monday and Wednesday routine. This new product iteration was almost directing itself. A new approach to sponsorship could be realised with existing industry partnership and a treasure trove began to materialise. Ticket sales were next on the list, and a real sense of excitement was building.

Strategic Management teams embraced the event as their own and were as committed to the success of the event as the Leadership in Action teams. To demonstrate the commitment, they immediately bought tickets worth \$150. The Strateghic Management teams continued to visit 'Chai Chat' to enjoy a cup of tea with their participating teams, to evaluate success and participate in the event and to help out as much as they could. The success of the event depended on the realisation of the 'commitment' by the lecturers and students - it was strongly suggested the money from ticket sales be realised for efficiency and better resource management. Essential concepts that the teams learned were that although commitments may add to the top-line for the revenue in the accounts, it will not add to the bottom-line unless the sales are realised. Efforts were made to reach out to all the committed parties who had not paid, and this helped to collect the money efficiently. 
Somehow the final event came together despite everything happening at once. Ticket sales for the auction were about half of what was anticipated but that just meant many people who bought a ticket realistically won a prize. We 'live-streamed' the auction with all its excitement. Students from across the campus were involved bringing in additional funds as they joined the Movember swan-song. It was a success.

\section{CONCLUSION}

Polytechnics are about the application and qualification in applied management that should lift the capabilities of students beyond theoretical research. The experiential approach to learning and teaching at OPAIC also has a focus on industry-relevant education. By using Agile methodologies with strategic management feedback, students developed a more profound, real-life understanding of collaborative Leadership in Action, with all its challenges and commitments. This article outlined some of the specific teaching strategies and management theories that formed the basis for Leadership in Action while reflecting on issues encountered and overcome in a Movember challenge on campus. All of the students in this article achieved their learning outcomes. An even more significant number of students came away with an experience that was authentic and fun, and that developed a positive campus culture while supporting our greater community.

In the final weeks of term, students completed their assessment and collected ' 30 -day, $\$ 30$ Challenge' pledges. To their surprise, almost everyone paid up. The financial team was busy documenting the financial results; the final tally was $\$ 1032.40$ donated to the Movember Foundation. It was less than our target but more than we thought we would raise. However, this project was not just about the total of the revenue generated. The experiential learning was invaluable, and we lived up to the intent of Leadership in Action. More courses could be explored, that have meaningful inter-connections between learning outcomes and real-life, authentic learning opportunities.

Rajeev Chawla is a Senior Lecturer in Applied Management and Hospitality Management at Otago Polytechnic Auckland International Campus. With an extensive business background in multi-cultural environments, he has a demonstrated record of achievement in business development, training talent and operations planning in corporate settings. He has spearheaded product initiatives, launched products and managed product lines in highly competitive environments.

(1) https://orcid.org/0000-0003-2744-5723

Marianne Cherrington is a Senior Lecturer at Otago Polytechnic Auckland International Campus, studying Computer Science and Analytics. A lecturer in disruptive innovation, her research into machine learning feature selection algorithms applies in many fields, and produces interesting collaborations with international partners in many disciplines and sectors.

(D) https://orcid.org/0000-0002-1240-2010

\section{REFERENCES}

Dann, L. (2018, December 29). Going Agile: Is Spark's big move the way your workplace is heading. New Zealand Herald. Retrieved from https://www.nzherald.co.nz/business/news/article.cfm?c_id=3\&objectid=12 103 I 50

Keane, B. (2017, June I). Whina Cooper and her Moko. Retrieved from www.teara.govt.nz: https://teara.govt.nz/en/ photograph/29689/whina-cooper-and-her-moko

Kolb, D. (1984). Experiential learning: Experience as the source of learning and development. Elglewood Cliffs: Prentice-Hall. 
Kropp, M., Meier, A., \& Biddle, R. (2016). Teaching Agile Collaboration Skills in Classroom. International Conference on Software Engineering Education and Training, 1/8-127. Dallas: IEEE 29th International Conference on Software Engineering Education and Training. https://doi.org/10.1109/CSEET.2016.27

Manning, G., \& Curtis, K. (2014). The Art of Leadership. New York: McGraw-Hill Education.

Movember. (2020, June). Movember. Retrieved from https://nz.movember.com/

Otago Polytechnic Auckland International Campus. (2019, November I). We launched Movember on campus today. [Facebook status update]. Retrieved from https://www.facebook.com/OtagoPolyAIC/posts/2454227/91334002

Parker, D., Holesgrove, M., \& Pathak, R. (20I5). Improving productivity with self-organised teams and agile leadership. International Journal and Performance Management, January 12, 112-128.

Seki, A. (2016). The Positive Effects of the Buddy Model in International Student Exchange. The Journal of Humanities and Natural Sciences, 73-90.

Sivers, D. (2010, February). How to Start a Movement. [TED Talks video file]. Retrieved from https://www.ted.com/talks/derek_ sivers_how_to_start_a_movement?language=en

Thunberg, G. (2018, November). The disarming case to act right now on climate change. [TED Talks video file]. Retrieved from https://www.ted.com/talks/greta_thunberg_the_disarming_case_to_act_right_now_on_climate_change

Tracy, B. (2017). Eat That Frog. Oakland: Berrett-Koehler publishers.

Yelkar, K. (2017, September 26). The Agile-Scrum Framework. C\# Corner. Retrieved https://www.c-sharpcorner.com/UploadFile/ d9c992/the-agile-scrum-framework/ 